\title{
Kreativitas Seorang Pelatih dalam Membangun Motivasi Berlatih pada Pemain Futsal (Studi Kasus Conan Futsal Academy)
}

Vicky Finley Sutirta, Gregorius Genep Sukendro vickyfs11@gmail.com,geneps@fikom.untar.ac.id

Fakultas Ilmu Komunikasi Universitas Tarumanagara

\begin{abstract}
Creativity is a person's ability to produce new compositions or anything that is a new foundation and previously unknown by the creator. Creativity is the ability to think to achieve varied and new results and the ability to be applied both in the fields of science, sports, literature and other fields of life can be used with creativity. Development of creativity to develop skills to combine creative power with experience, insight, and relationships with the environment for the better. Interpersonal communication theory that discusses the stages of interpersonal relationships, factors that influence interpersonal relationships. The purpose of interpersonal communication is to create motivation. This motivation is the ability of a coach in building the motivation of the players at Conan Futsal Academy. By using interpersonal communication, coaches use personal assistance to build players so they can help in training. The methodology in this study uses qualitative case study methods. Data collection obtained by interview, observation and literature study.
\end{abstract}

Keywords: coach creativity, motivation, interpersonal communication, conan futsal academy.

\begin{abstract}
Abstrak
Kreativitas adalah kemampuan seseorang untuk menghasilkan komposisi baru atau gagasan apa saja yang menjadi dasarnya baru dan sebelumnya tidak dikenal oleh pembuatnya. Kreativitas adalah kemampuan berpikir untuk meraih hasil yang variatif dan baru serta memungkinkan untuk diaplikasikan baik dalam bidang keilmuan, keolahragaan, kesusastraan maupun bidang kehidupan yang lain dapat berkaitan dengan kreativitas. Pengembangan kreativitas proses untuk mengembangkan kemampuan untuk mengkombinasikan daya kreatif dengan pengalaman, wawasan, maupun hubungan dengan lingkungan menjadi lebih baik. Teori komunikasi interpersonal mencakup tahapan hubungan interpersonal, faktor yang mempengaruhi hubungan interpersonal. Tujuan komunikasi interpersonal tersebut untuk menciptakan motivasi. Motivasi ini merupakan kemampuan dari seorang pelatih dalam membangun motivasi para pemain yang ada di Conan Futsal Academy. Dengan menggunakan komunikasi interpersonal pelatih menggunakan pendekatan secara personal untuk membangun motivasi pemain agar dapat semangat dalam berlatih. Metodologi dalam penelitian ini menggunakan kualitatif dengan metode studi kasus. Pengumpulan data yang didapat yaitu dengan wawancara, observasi dan studi kepustakaan.
\end{abstract}

Kata kunci: kreativitas pelatih, motivasi, komunikasi interpersonal, conan futsal academy. 


\section{Pendahuluan}

Olahraga adalah sebuah bentuk aktivitas fisik yang dilakukan secara terencana dan juga terstruktur yang melibatkan gerakan tubuh yang dilakukan secara berulang-ulang dan ditujukan untuk meningkatkan kebugaran jasmani. Olahraga merupakan sebagian kebutuhan pokok dalam kehidupan sehari-hari karena dapat meningkatkan kekebalan dan juga daya tahan tubuh seseorang.

Salah satu cabang olahraga yang cukup digemari kalangan manusia modern (Zaman sekarang) adalah Futsal. Futsal merupakan permainan olahraga yang dimainkan oleh dua tim yang masing-masing beranggotakan 5 orang. Tujuannya adalah untuk memasukkan bola kedalam gawang lawan, dengan teknik permainan bola dengan menggunakan kaki, (Wikipedia.com). Futsal menjadi olahraga yang praktis dan murah karena banyaknya sarana dan prasarana futsal sekarang ini dapat menjadi ajang bermain serta berkompetisi untuk yang hobi dalam olahraga tersebut. Futsal sendiri berasal dari Montevidio ibukota Uruguay, pada tahun 1930, oleh Juan Carlos Ceriani. Futsal sendiri berasal dari Bahasa Spanyol, yaitu futbol (sepakbola) dan sala (ruangan).

Dalam permainan futsal sangat diperlukan kemampuan mengandalkan fisik dan keterampilan (skill). Akan tetapi, dalam permainan futsal komunikasi sama pentingnya dalam membangun komunikasi sebuah tim untuk mencapai kesuksesan dalam tim. Oleh karena itu, Pelatih dan pemain merupakan bagian yang penting dalam sebuah tim futsal. Seorang pelatih futsal akan menggunakan komunikasi untuk menyampaikan apa yang dimaksudkan kepada pemainnya, berarti pelatih tersebut mengadakan komunikasi atau berhubungan dengan pemain dalam sebuah tim tersebut.

Komunikasi interpersonal seorang pelatih tidak akan tercapai apabila pelatih tidak dapat menyampaikan maksudnya dengan baik. Begitu juga dengan pemain apabila komunikasi yang disampaikan pada saat kondisi tidak kondusif maka tujuannya tidak akan maksimal. Oleh karena itu, peran sebagai pelatih yang kreatif dan membangun komunikasi secara baik sangat dibutuhkan dalam membentuk tim dan pemain yang berkarakter. Untuk itu penulis melakukan penelitian yang bertujuan untuk mengetahui bagaimana komunikasi interpersonal tersebut dapat berjalan dan juga bisa sampai kepada para pemain dalam tim,

Conan Futsal Academy adalah sebuah akademi futsal yang dibangun atau didirikan oleh Purwanto dan beberapa rekan-rekannya, ide awalnya adalah tadinya Purwanto ingin menjadi seorang pemain atau atlet namun karena jenjang waktu yang cukup telat akhirnya ia memutuskan untuk membangun akademi futsal tersebut guna untuk menyalurkan kemampuan atau pengalaman yang pernah ia dapatkan sehingga dapat melatih para pemain-pemain muda yang ingin mengembangkan bakatnya, khusus nya di daerah Kapuk Muara Jakarta Utara.

\section{Metode Penelitian}

Metode penelitian yang digunakan oleh penulis adalah penelitian kualitatif. Menurut Sugiono (2010:6), metode penelitian kualitatif adalah sebuah cara ilmiah agar mendapatkan data yang valid dengan tujuan yang ditemukan dan kemudian dikembangkan dan juga dibuktikan oleh pengetahuan tertentu sehingga pada gilirannya dapat digunakan untuk memahami serta memecahkan dan serta mengantisipasi masalah dalam bidang pendidikan. 
Menurut Moleong, penelitian kualitatif adalah penelitian yang digunakan untuk memahami tentang fenomena apa yang dialami oleh subjek penelitian, contohnya: perilaku, persepsi, tindakan dan motivasi secara holistic, melalui cara deskripsi dengan bentuk kata-kata dan juga bahasa, dalam suatu konteks khusus dengan memanfaatkan berbagai metode alamiah (Moleong, 2009:6).

Pada penelitian ini, studi kasus adalah metode penelitian kualitatif yang digunakan oleh penulis. Dalam metode studi kasus, subjek penelitian dapat mencakup individu, kelompok, lembaga serta masyarakat. Tujuan dari studi kasus ini adalah memberikan gambaran secara rinci mengenai latar belakang, sifat dan karakter yang khas dari kasus, dan status dari individu yang kemudian sifat-sifat khas tersebut akan dijadikan suatu hal yang bersifat umum. Studi kasus biasanya banyak digunakan pada penelitian desa, kota besar, kelompok manusia, pimpinan dan lainnya. (Nazir, 2011:57).

Penelitian ini dilakukan supaya peneliti dapat mengumpulkan dan mendapatkan pemahaman dan juga daya yang mendalam mengenai individu yang diteliti, dan masalah yang dihadapi supaya dapat diselesaikan dan membuat individu tersebut berkembang menjadi lebih baik.

Penulis menggunakan studi kasus untuk metode penelitian, dikarenakan penulis ingin mengetahui dan juga mengumpulkan informasi yang lebih mendalam pada kasus dan masalah yang ada. Penulis melihat kasus dan fenomena yang diambil adalah Conan Futsal Academy yang dimana pelatihnya mempunyai kreativitas dalam membangun motivasi berlatih para pemain futsal. Untuk mengumpulkan informasi tersebut penulis akan menggunakan metode wawancara, observasi, dan studi kepustakaan.

\section{Hasil Penemuan dan Diskusi}

Salah satunya kreativitas tercipta dalam dunia futsal khususnya hal kecil yang terjadi dalam Conan Futsal Academy. Kreativitas tersebut terbentuk oleh "tangan dingin" seorang pelatih. Sebagai pelatih Purwanto sendiri awalnya mempunyai ide untuk membentuk Futsal Academy. Dalam wawancara penulis dengan pelatih (pelatih conan), sang pelatih sendiri mengemukakan bahwa dikarenakan usia yang sudah lewat/ melampaui maka ia tidak dapat menjadi seorang atlet atau pemain Profesional. Maka muncul ide kreatif yang ia lakukan yaitu membentuk Conan Futsal Academy dan menyalurkan ilmu yang telah ia dapat. Berikut terpaparkan hasil wawancara singkat penulis dengan pelatih Conan Futsal Academy:

"Sebelumnya saya dan rekan futsal saya sama-sama ingin menjadi seorang atlet atau bisa disebut pemain profesional yang bermain di liga, namun berhubung saya sudah terlambat untuk menjadi atlet atau pemain pro tersebut akhirnya saya mempunyai ide bagaimana jika saya membuat academy futsal saja, akhirnya saya memutuskan untuk mengajak teman untuk bersama-sama mencoba untuk membentuk academy futsal tersebut, ya hitung-hitung juga sebagai sarana untuk menyalurkan bakat dan juga hobby anak-anak usia muda di sekitar wilayah Jakarta utara khususnya daerah Kapuk Muara dan juga sekitarnya."

"Bagaimana ya, sebenarnya itu hanya terlintas saja dipikiran saya lalu saya mencoba mendiskusikan kepada rekan saya dan akhirnya teman saya juga setuju dengan ide nama tersebut. Kan itu sebuah tokoh anime dari jepang ya, lalu juga saya cukup tertarik dengan tokoh itu. Terus karena tokohnya yang kecil dan cerdik menurut saya cukup dapat menarik nama yang digunakan, akhirnya ya sudah kami 
gunakan saja untuk membuat nama academy ini."

Pengembangan kreativitas yang dilakukan oleh Purwanto sendiri yaitu dengan melakukan modifikasi strategi atau materi latihan yang iya dapatkan melalui internet yang kemudian dikumpulkan dan juga diterapkan dalam latihan sehingga materi yang diberikan tidak monoton dan juga membosankan.

"sebenarnya cukup banyak yah, apalagi sebagai seorang pelatih saya harus dituntut sekreatif mungkin dan juga harus mengembangkan kreativitasnya bagaimana kreativitas saya yang saya lakukan seperti melihat cuplikan-cuplikan atau tayangan latihan yang ada di internet, lalu saya mencoba untuk memodifikasinya agar dapat lebih menarik ketika saat saya akan melatih. kalau untuk pengembangannya saat saya melatih materi yang saya berikan kepada pemain harus materi yang tidak monoton dan juga membosankan karena akan sangat berpengaruh kepada pemain yang berlatih, contohnya saja misalnya saat latihan koordinasi untuk fisik melalui pergerakannya setiap latihan pasti saya memberikan variasi yang berbeda-beda. lalu juga ada saat pemanasan dan juga pendinginan setelah selesai latihan."

"iya betul kalau untuk usia muda seperti mereka pastikan akan sangat bosan jika diberikan materi yang sama monoton sehingga pemain pun lama kelamaan merasa malas berlatih, tetapi jika saya berikan materi yang bervariasi kemungkinannya pemain tersebut akan tertantang untuk semangat berlatih."

Dalam hal ini Purwanto sendiri sebagai pelatih telah menerapkan komunikasi secara interpersonal kepada pemainnya sejak dari awal dibentuknya Futsal Academy ini. Menurut Purwanto pendekatan secara interpersonal ini sangat berpengaruh untuk dia sebagai seorang pelatih kepada para pemain futsal yang dilatih. Pendekatan yang dilakukan oleh pelatih dijelaskan sebagai berikut:

"Nah kalo itu saya melakukan pendekatan secara personal ya, misalnya ada kontak antara saya dan pemain diluar jam latihan dengan cara misalnya chatting atau yang lainnya. lalu saya berusaha untuk terlibat langsung jika ada pemain yang baru masuk agar dapat memberikan suasana yang nyaman kepada pemain baru tersebut sehingga dia tidak merasa canggung. saya sendiri selalu berharap agar semua pemain yang saya latih ini menciptakan keakraban yang adil satu sama lain, tidak pisah-pisah dan membedakan apabila itu pemain misalnya memang baru atau misalnya pemain tersebut memang kemampuannya masih kurang dari pemain yang lainnya. saya juga berusaha untuk bersikap terbuka dan harus saling percaya kepada pemain yang saya latih, sehingga ketika saya memberikan kritik kepada pemain, pemain tersebut tidak down atau merasa terintimidasi dengan kritik yang saya berikan, dan jika saya ada kesalahan juga mereka wajib menegur saya atau mengingatkan jika saya salah."

Seorang Pelatih memiliki sebuah cara untuk membuat para pemainnya dapat menjadi semangat berlatih. Dengan cara ini pelatih membangun motivasi yang dilakukan dengan cara yang cukup unik dan kreatif. Hal itu dilakukan agar dapat membangun semangat para pemainnya untuk dapat berlatih lebih giat. Purwanto sebagai pelatih dari Conan Futsal Academy membangun motivasi para pemainnya dengan cara membuat sebuah penghargaan atau bisa disebut reward/gift. Pemberian hadiah ini diberikan kepada pemain yang telah rajin berlatih dan mengalami peningkatan kemampuan atau (skill). Cara ini dilakukan oleh purwanto. Oleh karena itu, Purwanto berharap bahwa para pemainnya dapat menunjukkan kemampuan dan motivasi dalam berlatih. Berikut adalah wawancara singkat yang dilakukan penulis kepada pelatih Conan Futsal Academy: "Lalu motivasi yang saya berikan adalah ini cukup kreatif ya menurut saya, jadi dalam sebulan itu kan ada sekitar 8 kali latihan ya...." "Jadi dalam sebulan itu ada sekitar 8 kali latihan, jadi saya akan memantau 
Vicky Finley Sutirta, Gregorius Genep Sukendro: Kreativitas Seorang Pelatih dalam Membangun Motivasi Berlatih pada Pemain Futsal (Studi Kasus Conan Futsal Academy)

pemain yang berlatih nih.... jika selama 8 kali pertemuan tersebut pemain yang latihan ini konsisten, tidak pernah absen dalam latihan, lalu kemampuan atau skill nya semakin bertambah ketika latihan yang saya berikan, saya akan memberikan sebuah reward atau bisa dibilang sebuah gift yah... itu secara random, biasa nya giftnya itu bisa berupa peralatan untuk futsal, seperti sepatu, kaoskaki, baju latihan dan lain-lain."

\section{Simpulan}

Berdasarkan tinjauan penulis dalam menyimpulkan penelitian dengan judul "Kreativitas seorang pelatih dalam membangun motivasi berlatih pada pemain futsal" (Studi kasus pada Conan Futsal Academy), bahwa dalam mengangkat kreativitas dan motivasi yang ada di dalam Conan Futsal Academy ini. Penulis ingin menjelaskan bahwa seorang pelatih telah menjalankan teori komunikasi interpersonal dan kreativitas sudah berjalan dengan baik dan benar. Pertama, kreativitas yang ditunjukan oleh pelatih dengan menggunakan teori komunikasi interpersonal untuk melakukan kontak langsung dalam membangun/memberi motivasi kepada para pemain dan memberi reward atau gift apabila para pemain yang berlatih dengan baik. Hal ini menunjukkan bahwa salah satu bentuk kreativitas seorang pelatih.

Kedua, Pelatih memberikan metode latihan kepada pemain Conan Futsal Academy tidak monoton atau dalam bahasa lain tidak membosankan. Hal ini menunjukkan bahwa seorang pelatih selalu memiliki jiwa kreativitas untuk membangun sebuah tim. Disatu sisi pula, bahwa pelatih selalu memberi metode latihannya dengan melakukan hal-hal yang kreatif, seperti pemanasan dengan games, latihan fisik yang terlihat berat tapi menyenangkan dan memberikan formasi yang dapat dimengerti oleh pemain. Oleh karena itu, penulis menyimpulkan bahwa hal komunikasi dan kreativitas yang dibangun oleh pelatih untuk membentuk sebuah tim sungguh berjalan baik.

Disisi lain Conan Futsal Academy dalam mengiklankan atau mempromosikan academy ini kepada semua orang. Official Conan Futsal Academy mempunyai media sosial seperti Instagram, Youtube dan sebagainya yang dapat diakses oleh semua orang. Hal ini menunjukkan bahwa academy ini telah terbuka kepada siapa saja yang ingin berlatih futsal. Oleh karena itu, apabila ada orang yang berminat dapat bergabung ke dalam academy ini, dan bisa mengunjungi media sosial yang sudah tercantum dengan jelas.

Dalam pandangan penulis secara menyeluruh mengenai "Kreativitas seorang pelatih dalam membangun motivasi berlatih pada pemain futsal" (Studi kasus pada Conan Futsal Academy) ini. Penulis menyimpulkan bahwa hal kreativitas, teori komunikasi interpersonal dan periklanan ini telah berjalan cukup dengan baik. Bagaimana teori komunikasi interpersonal dan hal kreativitas dapat dibangun dengan baik di dalam akademi yang dilakukan oleh seorang pelatih. Hal ini menunjukkan bahwa akademi ini sungguh sehat. Begitu pula, dalam hal periklanan yang dapat menyaring dan memberikan Informasi untuk mengembangkan akademi ini. Oleh karena itu manfaat periklanan telah membantu untuk mengembangkan akademi tersebut. 


\section{Ucapan Terima Kasih}

Penulis memanjatkan rasa syukur dan terima kasih untuk penyelesaian dari penelitian ini kepada Fakultas Ilmu Komunikasi Universitas Tarumangara dan kepada para narasumber yang merupakan sumber dari penelitian yang telah bersedia untuk meluangkan waktunya serta semua pihak yang terlibat.

\section{Daftar Pustaka}

Lexy J, Moleong. 2009. Metode Penelitian Kualitatif. Bandung: Remaja Rosdakarya.

Moh, Nazir. 2011. Metode Penelitian. Bogor : Ghalia Indonesia.

Sugiyono. 2010. Metode Penelitian Pendidikan Pendekatan Kuantitatif, kualitatif, dan R\&D. Bandung: Alfabeta. 